\title{
SUBJECT INDEX 2019
}

1-butyl-3-methylimidazolium trifluoromethanesulfonate

Characterisation of an ionic liquid-based gel polymer electrolyte for potential applications (Prasadini K.W., Perera K.S. \& Vidanapathirana K.P.) 47: $133-138(2019)$

a dominated set-valued mapping

$\alpha$-dominated set-valued mappings and some generalised fixed point results (Shoaib A., Rasham T., Hussain N. \& Arshad M.) 47: 235-243 (2019)

\section{Adaptive cluster sampling}

Estimation of general parameter in adaptive cluster sampling using two auxiliary variables (Younis F. \& Shabbir J.) 47: 89-103 (2019)

\section{Aggregate interlocking}

Aggregate interlocking of open-graded friction courses with compaction effort (Mampearachchi W.K., Masakorala S.R. \& Umasangar K.) 47: 139$146(2019)$

\section{Alkaline cellulase}

Isolation of a cellulase producing Bacillus cereus from cow dung and determination of the kinetic properties of the crude enzyme (Croos A.M.B., Rajendran S. \& Ranganathan K.) 47: 261-267 (2019)

\section{Alleles}

Evaluating novel effective primers to amplify heterozygous alleles of second, third and fourth exons of HLA-A; -B; -C; -DRB1 and -DQB1 loci using sequencing-based typing (Perera P.C.D., Upamali B.D.N., Gunawardene Y.I.N.S. \& Dassanayake R.S.) 47: 341-348 (2019)

\section{Analogy}

Structural form as an analogical source for structures of nature: two examples (Dias P. \& Hahn R.) 47: 323-331 (2019)

\section{Anaximander}

Structural form as an analogical source for structures of nature: two examples (Dias P. \& Hahn R.) 47: 323-331 (2019)

\section{Animal and plant protein supplements}

Chemical composition and gross energy content of commonly available animal feedstuff in Sri Lanka (Pavithra S., Vidanarachchi J.K., Sarmini M. \& Premaratne S.) 47: 79-87 (2019)

\section{Antibiotic resistant genes (ARGs)}

Occurrence and distribution of tetracycline resistance determinants and their pollution profile in selected aquaculture environments in Sri Lanka (Liyanage G.Y. \& Manage P.M.) 47: 455-465 (2019)

\section{Aquaculture}

Occurrence and distribution of tetracycline resistance determinants and their pollution profile in selected aquaculture environments in Sri Lanka (Liyanage G.Y. \& Manage P.M.) 47: 455-465 (2019)

\section{Arabidopsis thaliana}

Effect of Macrophomina phaseolina on growth and expression of defense related genes in Arabidopsis thaliana (Saima S. \& Wu G.) 47: 113-120 (2019)

\section{Auxiliary variable}

Estimation of general parameter in adaptive cluster sampling using two auxiliary variables (Younis F. \& Shabbir J.) 47: 89-103 (2019)

\section{Auxiliary variable}

Utilising bivariate auxiliary information for enhanced estimation of population mean under simple and stratified random sampling schemes (Javed M., Irfan M. \& Pang T.) 47: 199-211 (2019)

\section{Auxis thazard}

Some biological aspects and molecular variations in frigate tuna, Auxis thazard of the coastal waters around Sri Lanka (Herath D.R., Perera H.A.C.C. \& Hettiarachchi G.H.C.M.) 47: 333-340 (2019)

\section{Bacillus cereus}

Isolation of a cellulase producing Bacillus cereus from cow dung and determination of the kinetic properties of the crude enzyme (Croos A.M.B., Rajendran S. \& Ranganathan K.) 47: 261-267 (2019)

\section{Bacterial biomarkers}

Molecular indicators of early stage diagenesis in the tropical coastal Bolgoda Lake, Sri Lanka (Ratnayake A.S., Sampei Y. \& Ratnayake N.P.) 47: 69-77 (2019)

\section{Bangladesh}

Effect of micronutrient fortified fertiliser application on the growth and yield components of tomato plant in floodplain soils of Bangladesh (Sarker Md. M.H., Moslehuddin A.Z. Md., Jahiruddin M., Islam M.R. \& Talukder R.) 47: 161-168 (2019) 
Best linear unbiased estimator

Estimation of the parameters in two linear models with some of the identical parameter vectors under the Pitman's closeness criterion (Wu J.) 47 : 363-368 (2019)

Bias

Utilising bivariate auxiliary information for enhanced estimation of population mean under simple and stratified random sampling schemes (Javed M. Irfan M. \& Pang T.) 47: 199-211 (2019)

\section{Buckminsterfullerene}

Structural form as an analogical source for structures of nature: two examples (Dias P. \& Hahn R.) 47: 323-331 (2019)

\section{Calcium carbonate}

Effect of an organotitanate coupling agent on properties of calcium carbonate filled low-density polyethylene and natural rubber composites (Sampath W.D.M., Egodage S.M. \& Edirisinghe D.G.) 47: 17-27 (2019)

\section{Calcium hydroxide}

Durability properties of alkali pozzolan cement (APC) (Kulasuriya C., Dias W.P.S. \& Vimonsatit V.) 47: 121-131 (2019)

\section{Carbonation}

Durability properties of alkali pozzolan cement (APC) (Kulasuriya C., Dias W.P.S. \& Vimonsatit V.) 47: 121-131 (2019)

\section{Cauchy completion}

Zp as a final coalgebra obtained by Cauchy completing the initial algebra (Manokaran A., Ratnayake J. \& Jayewardene R.) 47: 105-112 (2019)

\section{Chemical weathering}

Sedimentary geochemistry of alluvial overburden in the primary gem deposit of Pelmadulla, Sri Lanka (Jayawardana D.T., Madusanka R.M.T.D., Jayasinghe R.M.N.P.K., Adikaram A.M.N.M. \& Udagedara D.T.) 47: 221-234 (2019)

\section{Chloride ion penetration}

Durability properties of alkali pozzolan cement (APC) (Kulasuriya C., Dias W.P.S. \& Vimonsatit V.) 47: 121-131 (2019)

\section{Cinnamomum verum}

Intensity of leaf spot and rough bark diseases in cinnamon accessions collected from major cinnamon growing areas of Sri Lanka (Azad R., Kumara K.L.W., Senanayake G., Ranawaka R.A.A.K., Pushpakumara D.K.N.G. \& Geekiyanage S.) 47: 297-305 (2019)

\section{Classifier chain algorithms}

Efficient label ordering for improving multi-label classifier chain accuracy (Ali T. \& Asghar S.) 47: 175-184 (2019)

\section{Closed ball}

$\alpha$-dominated set-valued mappings and some generalised fixed point results (Shoaib A., Rasham T., Hussain N. \& Arshad M.) 47: 235-243 (2019)

\section{Cluster analysis}

Intensity of leaf spot and rough bark diseases in cinnamon accessions collected from major cinnamon growing areas of Sri Lanka (Azad R., Kumara K.L.W., Senanayake G., Ranawaka R.A.A.K., Pushpakumara D.K.N.G. \& Geekiyanage S.) 47: 297-305 (2019)

\section{CMC agar media}

Isolation of a cellulase producing Bacillus cereus from cow dung and determination of the kinetic properties of the crude enzyme (Croos A.M.B., Rajendran S. \& Ranganathan K.) 47: 261-267 (2019)

\section{Coconut testa flour}

Comparison of inter-varietal differences in chemical composition and nutritional properties of coconut testa flour (Marasinghe S.S.K., Marikkar J.M.N., Yalegama C., Wimalasiri S., Seneviratne G., Weerasooriya R. \& Liyanage R.) 47: 349-356 (2019)

\section{Coconut}

Comparison of inter-varietal differences in chemical composition and nutritional properties of coconut testa flour (Marasinghe S.S.K., Marikkar J.M.N., Yalegama C., Wimalasiri S., Seneviratne G., Weerasooriya R. \& Liyanage R.) 47: 349-356 (2019)

\section{Coefficient of variation}

Estimation of general parameter in adaptive cluster sampling using two auxiliary variables (Younis F. \& Shabbir J.) 47: 89-103 (2019)

\section{Cognitive radio}

Human opinion dynamics-based optimization for in-band spectrum sensing in cognitive radio networks (Garg R. \& Saluja N.) 47: 467-477 (2019)

\section{Common fixed point}

$\alpha$-dominated set-valued mappings and some generalised fixed point results (Shoaib A., Rasham T., Hussain N. \& Arshad M.) 47: 235-243 (2019)

\section{Common parameters}

Estimation of the parameters in two linear models with some of the identical parameter vectors under the Pitman's closeness criterion (Wu J.) 47 : 363-368 (2019) 
Complete dislocated b-metric space

$\alpha$-dominated set-valued mappings and some generalised fixed point results (Shoaib A., Rasham T., Hussain N. \& Arshad M.) 47: 235-243 (2019)

\section{Complex hybrid systems}

Integrating runtime validation and hardware-in-the-loop (HiL) testing with V \& V in complex hybrid systems (Dewasurendra S.D., Vidarapathirana A.C. \& Abeyratne S.G.) 47: 393-408 (2019)

\section{Compositional testing}

Integrating runtime validation and hardware-in-the-loop (HiL) testing with V \& V in complex hybrid systems (Dewasurendra S.D., Vidarapathirana A.C. \& Abeyratne S.G.) 47: 393-408 (2019)

\section{Compositional verification}

Integrating runtime validation and hardware-in-the-loop (HiL) testing with V \& V in complex hybrid systems (Dewasurendra S.D., Vidarapathirana A.C. \& Abeyratne S.G.) 47: 393-408 (2019)

\section{Conducting polymer}

Silver-montmorillonite-conducting polymer composite materials as low-cost oxygen reduction catalysts (Senarathna K.G.C. \& Rajapakse R.M.G.) 47: 409-420 (2019)

\section{Correlation coefficient}

Mapping ilmenite deposit in Pulmudai, Sri Lanka using a hyperspectral imaging-based surface mineral mapping method (Ekanayake E.M.M.B., Vithana S.S.P., Ekanayake E.M.H.E.B., Rathnayake A.R.M.A.N., Abeysekara A.M.R., Oorloff T.S.J., Herath H.M.V.R., Godaliyadda G.M.R.I., Ekanayake M.P.B. \& Senaratne A.) 47: 271-284 (2019)

\section{Cow dung}

Isolation of a cellulase producing Bacillus cereus from cow dung and determination of the kinetic properties of the crude enzyme (Croos A.M.B., Rajendran S. \& Ranganathan K.) 47: 261-267 (2019)

\section{Cyanobacteria}

Geosmin contamination status of raw and treated waters in Sri Lanka (Ganegoda S., Chinthaka S.D.M. \& Manage P.M) 47: 245-259 (2019)

\section{Data engineering}

Mapping ilmenite deposit in Pulmudai, Sri Lanka using a hyperspectral imaging-based surface mineral mapping method (Ekanayake E.M.M.B., Vithana S.S.P., Ekanayake E.M.H.E.B., Rathnayake A.R.M.A.N., Abeysekara A.M.R., Oorloff T.S.J., Herath H.M.V.R., Godaliyadda G.M.R.I., Ekanayake M.P.B. \& Senaratne A.) 47: 271-284 (2019)

\section{Data mining}

Efficient label ordering for improving multi-label classifier chain accuracy (Ali T. \& Asghar S.) 47: 175-184 (2019)

\section{Decomposition}

Austroeupatorium inulifolium invasion alters litter dynamics in Cymbopogon nardus-dominated manmade grasslands (Piyasinghe I.P.K., Gunatilake J. \& Madawala H.M.S.P.) 47: 39-49 (2019)

\section{Degraded grasslands}

Austroeupatorium inulifolium invasion alters litter dynamics in Cymbopogon nardus-dominated manmade grasslands (Piyasinghe I.P.K., Gunatilake J. \& Madawala H.M.S.P.) 47: 39-49 (2019)

\section{Degree-based topological index}

Computational aspects of line graph of carbon nanocones (Hussain Z., Munir M., Nazeer W., Saleem M.S., Kang S.M. \& Kwun Y.C.) 47: $435-443$ (2019)

\section{Deterministic and stochastic pedestrian flows}

Comparative study of deterministic and stochastic pedestrian motions (Pradhan R.K., Shrestha S. \& Tiwari S.) 47: 213-220 (2019)

\section{Diagonal shear test}

Performance of un-reinforced burned clay brick masonry walls retrofitted with locally available materials (Mendis W.S.W., De Silva G.S.Y. \& De Silva G.H.M.J.S.) 47: 29-38 (2019)

\section{Digital libraries}

Efficient label ordering for improving multi-label classifier chain accuracy (Ali T. \& Asghar S.) 47: 175-184 (2019)

\section{Drought tolerance}

Germination and seedling growth responses of Sri Lankan grown sesame/thala (Sesamum indicum L.) for simulated drought Conditions (Dissanayake I.A.J.K., Ranwala S.M.W. \& Perera S.S.N.) 47: 479-490 (2019)

\section{Dry days}

Trends in extreme rainfall events in Sri Lanka,1961-2010 (Thevakaran A., Suppiah R. \& Sonnadara U.) 47: 285-295 (2019)

\section{Electrocatalyst}

Silver-montmorillonite-conducting polymer composite materials as low-cost oxygen reduction catalysts (Senarathna K.G.C. \& Rajapakse R.M.G.) 47: 409-420 (2019) 
Electrochemical impedance spectroscopy

Characterisation of an ionic liquid-based gel polymer electrolyte for potential applications (Prasadini K.W., Perera K.S. \& Vidanapathirana K.P.) 47: 133-138 (2019)

\section{Electrochemical stability window}

Characterisation of an ionic liquid-based gel polymer electrolyte for potential applications (Prasadini K.W., Perera K.S. \& Vidanapathirana K.P.) 47: 133-138 (2019)

\section{Elegance}

Structural form as an analogical source for structures of nature: two examples (Dias P. \& Hahn R.) 47: 323-331 (2019)

\section{Energy supplements}

Chemical composition and gross energy content of commonly available animal feedstuff in Sri Lanka (Pavithra S., Vidanarachchi J.K., Sarmini M. \& Premaratne S.) 47: 79-87 (2019)

\section{ERA Interim}

Numerical modelling of the spatial variation of sediment transport using wave climate schematization method - a case study of west coast of Sri Lanka (Jayathilaka R.M.R.M. \& Fernando M.C.S.) 47: 421-433 (2019)

\section{Extreme events}

Trends in extreme rainfall events in Sri Lanka,1961-2010 (Thevakaran A., Suppiah R. \& Sonnadara U.) 47: 285-295 (2019)

Fatty acids

Comparison of inter-varietal differences in chemical composition and nutritional properties of coconut testa flour (Marasinghe S.S.K., Marikkar J.M.N., Yalegama C., Wimalasiri S., Seneviratne G., Weerasooriya R. \& Liyanage R.) 47: 349-356 (2019)

\section{Feeding}

Some biological aspects and molecular variations in frigate tuna, Auxis thazard of the coastal waters around Sri Lanka (Herath D.R., Perera H.A.C.C. \& Hettiarachchi G.H.C.M.) 47: 333-340 (2019)

\section{Fermented banana flour}

Isolation and identification of lactic acid bacteria with probiotic potential from fermented flour of selected banana varieties grown in Sri Lanka (Divisekera D.M.W.D., Samarasekera J.K.R.R., Hettiarachchi C., Gooneratne J., Choudhary M.I. \& Gopalakrishnan S.) 47: 3-6 (2019)

\section{Fifth leaf stage}

Varietal diversity of Sri Lankan traditional rice based on sensitivity to temperature and photoperiod at vegetative stage (Rathnathunga E.U.U., Senanayake G., Seneweera S. \& Geekiyanage S.) 47: 51-68 (2019)

\section{Final coalgebra}

Zp as a final coalgebra obtained by Cauchy completing the initial algebra (Manokaran A., Ratnayake J. \& Jayewardene R.) 47: 105-112 (2019)

\section{Fisher's discriminant analysis}

Mapping ilmenite deposit in Pulmudai, Sri Lanka using a hyperspectral imaging-based surface mineral mapping method (Ekanayake E.M.M.B., Vithana S.S.P., Ekanayake E.M.H.E.B., Rathnayake A.R.M.A.N., Abeysekara A.M.R., Oorloff T.S.J., Herath H.M.V.R., Godaliyadda G.M.R.I., Ekanayake M.P.B. \& Senaratne A.) 47: 271-284 (2019)

\section{Floodplain soil}

Effect of micronutrient fortified fertiliser application on the growth and yield components of tomato plant in floodplain soils of Bangladesh (Sarker Md. M.H., Moslehuddin A.Z. Md., Jahiruddin M., Islam M.R. \& Talukder R.) 47: 161-168 (2019)

\section{Fractional nonlinear evolution equations}

Closed form wave solutions to the time fractional Boussinesq-type equation and the Zakharov-Kuznetsov equation (Islam M.N., Khan Md. A. \& Akbar M.A.) 47: 149-160 (2019)

\section{Frigate tuna}

Some biological aspects and molecular variations in frigate tuna, Auxis thazard of the coastal waters around Sri Lanka (Herath D.R., Perera H.A.C.C. \& Hettiarachchi G.H.C.M.) 47: 333-340 (2019)

\section{Gamma family of distribution}

On gamma inverse Weibull distribution (Abbas S., Hameed M., Cakmakyapan S. \& Malik S.N.) 47: 445-453 (2019)

\section{Gas chromatography-mass spectrometry}

Geosmin contamination status of raw and treated waters in Sri Lanka (Ganegoda S., Chinthaka S.D.M. \& Manage P.M.) 47: $245-259$ (2019)

\section{Gel polymer electrolytes}

Characterisation of an ionic liquid-based gel polymer electrolyte for potential applications (Prasadini K.W., Perera K.S., \& Vidanapathirana K.P.) 47: 133-138 (2019)

\section{Gene expression}

Effect of Macrophomina phaseolina on growth and expression of defense related genes in Arabidopsis thaliana (Saima S. \& Wu G.) 47: 113-120 (2019) 


\section{General coefficient}

On gamma inverse Weibull distribution (Abbas S., Hameed M., Cakmakyapan S. \& Malik S.N.) 47: 445-453 (2019)

\section{General Randic index}

Computational aspects of line graph of carbon nanocones (Hussain Z., Munir M., Nazeer W., Saleem M.S., Kang S.M. \& Kwun Y.C.) 47: 435-443 (2019)

\section{Generalized $\left(G^{1} / G\right)$-expansion method}

Closed form wave solutions to the time fractional Boussinesq-type equation and the Zakharov-Kuznetsov equation (Islam M.N., Khan Md. A. \& Akbar M.A.) 47: 149-160 (2019)

\section{Geometry}

Structural form as an analogical source for structures of nature: two examples (Dias P. \& Hahn R.) 47: 323-331 (2019)

\section{Geosmin}

Geosmin contamination status of raw and treated waters in Sri Lanka (Ganegoda S., Chinthaka S.D.M. \& Manage P.M.) 47: 245-259 (2019)

\section{Germination}

Germination and seedling growth responses of Sri Lankan grown sesame/thala (Sesamum indicum L.) for simulated drought Conditions (Dissanayake I.A.J.K., Ranwala S.M.W. \& Perera S.S.N.) 47: 479-490 (2019)

\section{Gingelly}

Germination and seedling growth responses of Sri Lankan grown sesame/thala (Sesamum indicum L.) for simulated drought Conditions (Dissanayake I.A.J.K., Ranwala S.M.W. \& Perera S.S.N.) 47: 479-490 (2019)

\section{GluB-1 promoter}

Cloning and characterization of an endosperm specific glutelin Blpromoter from Sri Lankan rice (Oryza sativa L. ssp. indica) variety Bg 250 (Kajendran K., Chandrasekharan N.V., Hettiarachchi C.M., Nanayakkara A.K., Elvitigala A.S. \& Wijesundera W.S.S.) 47: 383-391 (2019)

\section{Graph dominated mapping}

$\alpha$-dominated set-valued mappings and some generalised fixed point results (Shoaib A., Rasham T., Hussain N. \& Arshad M.) 47: 235-243 (2019)

\section{Grasses and tree species}

Chemical composition and gross energy content of commonly available animal feedstuff in Sri Lanka (Pavithra S., Vidanarachchi J.K., Sarmini M. \& Premaratne S.) 47: 79-87 (2019)

\section{Growth}

Some biological aspects and molecular variations in frigate tuna, Auxis thazard of the coastal waters around Sri Lanka (Herath D.R., Perera H.A.C.C. \& Hettiarachchi G.H.C.M.) 47: 333-340 (2019)

\section{Hardware-in-the-loop testing}

Integrating runtime validation and hardware-in-the-loop (HiL) testing with $\mathrm{V} \& \mathrm{~V}$ in complex hybrid systems (Dewasurendra S.D., Vidarapathirana A.C. \& Abeyratne S.G.) 47: 393-408 (2019)

\section{Headspace solid-phase micro extraction}

Geosmin contamination status of raw and treated waters in Sri Lanka (Ganegoda S., Chinthaka S.D.M. \& Manage P.M.) 47: 245-259 (2019)

\section{Hopane}

Molecular indicators of early stage diagenesis in the tropical coastal Bolgoda Lake, Sri Lanka (Ratnayake A.S., Sampei Y. \& Ratnayake N.P.) 47: 69-77 (2019)

\section{Hosoya polynomial}

Hosoya polynomial and topological indices of $n$-linear benzene (Nizami A.R., Idrees M., Amin N. \& Iqbal Z.) 47: 169-174 (2019)

\section{Human and vector population}

Mathematical model for malaria with mosquito-dependent coefficient for human population with exposed class (Singh R., Ali S., Jain M. \& Raina A.A.) 47: $185-198$ (2019)

\section{Human leukocyte antigen (HLA) typing}

Evaluating novel effective primers to amplify heterozygous alleles of second, third and fourth exons of HLA-A; -B; -C; -DRB1 and -DQB1 loci using sequencing-based typing (Perera P.C.D., Upamali B.D.N., Gunawardene Y.I.N.S. \& Dassanayake R.S.) 47: 341-348 (2019)

\section{Human opinion dynamics}

Human opinion dynamics-based optimization for in-band spectrum sensing in cognitive radio networks (Garg R. \& Saluja N.) 47: 467-477 (2019)

Initial algebra

Zp as a final coalgebra obtained by Cauchy completing the initial algebra (Manokaran A., Ratnayake J. \& Jayewardene R.) 47: 105-112 (2019)

\section{In-plane load}

Performance of un-reinforced burned clay brick masonry walls retrofitted with locally available materials (Mendis W.S.W., De Silva G.S.Y. \& De Silva G.H.M.J.S.) 47: 29-38 (2019) 
Inverse Weibull distribution

On gamma inverse Weibull distribution (Abbas S., Hameed M., Cakmakyapan S. \& Malik S.N.) 47: 445-453 (2019)

Ionic liquids

Characterisation of an ionic liquid-based gel polymer electrolyte for potential applications (Prasadini K.W., Perera K.S. \& Vidanapathirana K.P.) 47: $133-138$ (2019)

\section{KMD gates}

Design of fault-tolerant reversible Vedic multiplier in quantum cellular automata (Kamaraj A. \& Marichamy P.) 47: 371-382 (2019)

\section{Lactic acid bacteria}

Isolation and identification of lactic acid bacteria with probiotic potential from fermented flour of selected banana varieties grown in Sri Lanka (Divisekera D.M.W.D., Samarasekera J.K.R.R., Hettiarachchi C., Gooneratne J., Choudhary M.I. \& Gopalakrishnan S.) 47: 3-6 (2019)

\section{Lanka basin}

Estimating sedimentary thickness of Lanka Basin using digitized scanned seismic sections (Silva K.C.C., Gamage N.G.S.S. \& Weerasinghe D.A.) 47: 357-362 (2019)

\section{Leaf spot disease severity}

Intensity of leaf spot and rough bark diseases in cinnamon accessions collected from major cinnamon growing areas of Sri Lanka (Azad R., Kumara K.L.W., Senanayake G., Ranawaka R.A.A.K., Pushpakumara D.K.N.G. \& Geekiyanage S.) 47: 297-305 (2019)

\section{Line graph}

Computational aspects of line graph of carbon nanocones (Hussain Z., Munir M., Nazeer W., Saleem M.S., Kang S.M. \& Kwun Y.C.) 47: 435-443 (2019)

\section{Linear benzene}

Hosoya polynomial and topological indices of $n$-linear benzene (Nizami A.R., Idrees M., Amin N. \& Iqbal Z.) 47: 169-174 (2019)

\section{Litter inputs}

Austroeupatorium inulifolium invasion alters litter dynamics in Cymbopogon nardus-dominated manmade grasslands (Piyasinghe I.P.K., Gunatilake J. \& Madawala H.M.S.P.) 47: 39-49 (2019)

\section{Litter quality}

Austroeupatorium inulifolium invasion alters litter dynamics in Cymbopogon nardus-dominated manmade grasslands (Piyasinghe I.P.K., Gunatilake J. \& Madawala H.M.S.P.) 47: 39-49 (2019)

\section{Low density polyethylene}

Effect of an organotitanate coupling agent on properties of calcium carbonate filled low-density polyethylene and natural rubber composites (Sampath W.D.M., Egodage S.M. \& Edirisinghe D.G.) 47: 17-27 (2019)

\section{Macrophomina phaseolina}

Effect of Macrophomina phaseolina on growth and expression of defense related genes in Arabidopsis thaliana (Saima S. \& Wu G.) 47: 113-120 (2019)

\section{Maximum likelihood}

On gamma inverse Weibull distribution (Abbas S., Hameed M., Cakmakyapan S. \& Malik S.N.) 47: 445-453 (2019)

\section{Mean squared error}

Estimation of the parameters in two linear models with some of the identical parameter vectors under the Pitman's closeness criterion (Wu J.) 47: 363-368 (2019)

\section{Mean squared error}

Utilising bivariate auxiliary information for enhanced estimation of population mean under simple and stratified random sampling schemes (Javed M., Irfan M. \& Pang T.) 47: 199-211 (2019)

\section{Microminerals}

Comparison of inter-varietal differences in chemical composition and nutritional properties of coconut testa flour (Marasinghe S.S.K., Marikkar J.M.N., Yalegama C., Wimalasiri S., Seneviratne G., Weerasooriya R. \& Liyanage R.) 47: 349-356 (2019)

\section{Micronutrients}

Effect of micronutrient fortified fertiliser application on the growth and yield components of tomato plant in floodplain soils of Bangladesh (Sarker Md. M.H., Moslehuddin A.Z. Md., Jahiruddin M., Islam M.R. \& Talukder R.) 47: 161-168 (2019)

\section{Microscopic model}

Comparative study of deterministic and stochastic pedestrian motions (Pradhan R.K., Shrestha S. \& Tiwari S.) 47: 213-220 (2019)

Minerals

Chemical composition and gross energy content of commonly available animal feedstuff in Sri Lanka (Pavithra S., Vidanarachchi J.K., Sarmini M. \& Premaratne S.) 47: 79-87 (2019) 
Monsoons

Trends in extreme rainfall events in Sri Lanka,1961-2010 (Thevakaran A., Suppiah R. \& Sonnadara U.) 47: 285-295 (2019)

Montmorillonite

Silver-montmorillonite-conducting polymer composite materials as low-cost oxygen reduction catalysts (Senarathna K.G.C. \& Rajapakse R.M.G.) 47: 409-420 (2019)

\section{Morphodynamics}

Numerical modelling of the spatial variation of sediment transport using wave climate schematization method - a case study of west coast of Sri Lanka (Jayathilaka R.M.R.M. \& Fernando M.C.S.) 47: 421-433 (2019)

Morphological acceleration

Numerical modelling of the spatial variation of sediment transport using wave climate schematization method - a case study of west coast of Sri Lanka (Jayathilaka R.M.R.M. \& Fernando M.C.S.) 47: 421-433 (2019)

M-polynomial

Computational aspects of line graph of carbon nanocones (Hussain Z., Munir M., Nazeer W., Saleem M.S., Kang S.M. \& Kwun Y.C.) 47: 435-443 (2019)

Multi-label classification

Efficient label ordering for improving multi-label classifier chain accuracy (Ali T. \& Asghar S.) 47: 175-184 (2019)

Nachchaduwa

Distributed modelling of water resources and pollute transport in Malwathu Oya Basin, Sri Lanka (Dahanayake A.C. \& Rajapakse R.L.H.L.) 47: 307-321 (2019)

Natural rubber

Effect of an organotitanate coupling agent on properties of calcium carbonate filled low-density polyethylene and natural rubber composites (Sampath W.D.M., Egodage S.M. \& Edirisinghe D.G.) 47: 17-27 (2019)

Necrotrophic fungus

Effect of Macrophomina phaseolina on growth and expression of defense related genes in Arabidopsis thaliana (Saima S. \& Wu G.) 47: 113-120 (2019)

NGDC

Estimating sedimentary thickness of Lanka Basin using digitized scanned seismic sections (Silva K.C.C., Gamage N.G.S.S. \& Weerasinghe D.A.) 47: 357-362 (2019)

\section{Nitrogen}

Distributed modelling of water resources and pollute transport in Malwathu Oya Basin, Sri Lanka (Dahanayake A.C. \& Rajapakse R.L.H.L.) 47: 307-321 (2019)

\section{Nutrient concentrations}

Distributed modelling of water resources and pollute transport in Malwathu Oya Basin, Sri Lanka (Dahanayake A.C. \& Rajapakse R.L.H.L.) 47: 307-321 (2019)

\section{Nutrient release patterns}

Austroeupatorium inulifolium invasion alters litter dynamics in Cymbopogon nardus-dominated manmade grasslands (Piyasinghe I.P.K., Gunatilake J. \& Madawala H.M.S.P.) 47: 39-49 (2019)

\section{OGFC}

Aggregate interlocking of open-graded friction courses with compaction effort (Mampearachchi W.K., Masakorala S.R. \& Umasangar K.) 47: 139$146(2019)$

Optimum compaction

Aggregate interlocking of open-graded friction courses with compaction effort (Mampearachchi W.K., Masakorala S.R. \& Umasangar K.) 47: 139$146(2019)$

\section{Oryza sativa}

Varietal diversity of Sri Lankan traditional rice based on sensitivity to temperature and photoperiod at vegetative stage (Rathnathunga E.U.U., Senanayake G., Seneweera S. \& Geekiyanage S.) 47: 51-68 (2019)

\section{Oxygen reduction reaction}

Silver-montmorillonite-conducting polymer composite materials as low-cost oxygen reduction catalysts (Senarathna K.G.C. \& Rajapakse R.M.G.) 47: 409-420 (2019)

\section{$P$-adic integers}

Zp as a final coalgebra obtained by Cauchy completing the initial algebra (Manokaran A., Ratnayake J. \& Jayewardene R.) 47: 105-112 (2019)

\section{Partial order}

$\alpha$-dominated set-valued mappings and some generalised fixed point results (Shoaib A., Rasham T., Hussain N. \& Arshad M.) 47: 235-243 (2019) 
Passive margins

Estimating sedimentary thickness of Lanka Basin using digitized scanned seismic sections (Silva K.C.C., Gamage N.G.S.S. \& Weerasinghe D.A.) 47: 357-362 (2019)

\section{Pathogenesis related proteins}

Effect of Macrophomina phaseolina on growth and expression of defense related genes in Arabidopsis thaliana (Saima S. \& Wu G.) 47: 113-120 (2019)

PCR

Evaluating novel effective primers to amplify heterozygous alleles of second, third and fourth exons of HLA-A; -B; -C; -DRB1 and -DQB1 loci using sequencing-based typing (Perera P.C.D., Upamali B.D.N., Gunawardene Y.I.N.S. \& Dassanayake R.S.) 47: 341-348 (2019)

\section{Pedestrian flow}

Comparative study of deterministic and stochastic pedestrian motions (Pradhan R.K., Shrestha S. \& Tiwari S.) 47: 213-220 (2019)

\section{Percent relative efficiency}

Utilising bivariate auxiliary information for enhanced estimation of population mean under simple and stratified random sampling schemes (Javed M., Irfan M. \& Pang T.) 47: 199-211 (2019)

\section{Phosphorus}

Distributed modelling of water resources and pollute transport in Malwathu Oya Basin, Sri Lanka (Dahanayake A.C. \& Rajapakse R.L.H.L.) 47: 307-321 (2019)

\section{Photoperiod sensitivity}

Varietal diversity of Sri Lankan traditional rice based on sensitivity to temperature and photoperiod at vegetative stage (Rathnathunga E.U.U., Senanayake G., Seneweera S. \& Geekiyanage S.) 47: 51-68 (2019)

\section{Physico-mechanical properties}

Effect of an organotitanate coupling agent on properties of calcium carbonate filled low-density polyethylene and natural rubber composites (Sampath W.D.M., Egodage S.M. \& Edirisinghe D.G.) 47: 17-27 (2019)

\section{Pitman's closeness criterion}

Estimation of the parameters in two linear models with some of the identical parameter vectors under the Pitman's closeness criterion (Wu J.) 47: 363-368 (2019)

\section{Polymorphism}

Evaluating novel effective primers to amplify heterozygous alleles of second, third and fourth exons of HLA-A; -B; -C; -DRB1 and -DQB1 loci using sequencing-based typing (Perera P.C.D., Upamali B.D.N., Gunawardene Y.I.N.S. \& Dassanayake R.S.) 47: 341-348 (2019)

\section{Primary gem}

Sedimentary geochemistry of alluvial overburden in the primary gem deposit of Pelmadulla, Sri Lanka (Jayawardana D.T., Madusanka R.M.T.D., Jayasinghe R.M.N.P.K., Adikaram A.M.N.M. \& Udagedara D.T.) 47: 221-234 (2019)

\section{Primary user}

Human opinion dynamics-based optimization for in-band spectrum sensing in cognitive radio networks (Garg R. \& Saluja N.) 47: 467-477 (2019)

\section{Principal component analysis}

Mapping ilmenite deposit in Pulmudai, Sri Lanka using a hyperspectral imaging-based surface mineral mapping method (Ekanayake E.M.M.B., Vithana S.S.P., Ekanayake E.M.H.E.B., Rathnayake A.R.M.A.N., Abeysekara A.M.R., Oorloff T.S.J., Herath H.M.V.R., Godaliyadda G.M.R.I., Ekanayake M.P.B. \& Senaratne A.) 47: 271-284 (2019)

\section{Probability-based approach}

Mapping ilmenite deposit in Pulmudai, Sri Lanka using a hyperspectral imaging-based surface mineral mapping method (Ekanayake E.M.M.B., Vithana S.S.P., Ekanayake E.M.H.E.B., Rathnayake A.R.M.A.N., Abeysekara A.M.R., Oorloff T.S.J., Herath H.M.V.R., Godaliyadda G.M.R.I., Ekanayake M.P.B. \& Senaratne A.) 47: 271-284 (2019)

\section{Probiotics}

Isolation and identification of lactic acid bacteria with probiotic potential from fermented flour of selected banana varieties grown in Sri Lanka (Divisekera D.M.W.D., Samarasekera J.K.R.R., Hettiarachchi C., Gooneratne J., Choudhary M.I. \& Gopalakrishnan S.) 47: 3-6 (2019)

\section{Proximate composition}

Comparison of inter-varietal differences in chemical composition and nutritional properties of coconut testa flour (Marasinghe S.S.K., Marikkar J.M.N., Yalegama C., Wimalasiri S., Seneviratne G., Weerasooriya R. \& Liyanage R.) 47: 349-356 (2019)

\section{Recent sediments}

Molecular indicators of early stage diagenesis in the tropical coastal Bolgoda Lake, Sri Lanka (Ratnayake A.S., Sampei Y. \& Ratnayake N.P.) 47: 69-77 (2019)

\section{Region of convergence}

Human opinion dynamics-based optimization for in-band spectrum sensing in cognitive radio networks (Garg R. \& Saluja N.) 47: 467-477 (2019) 
Remote sensing

Mapping ilmenite deposit in Pulmudai, Sri Lanka using a hyperspectral imaging-based surface mineral mapping method (Ekanayake E.M.M.B., Vithana S.S.P., Ekanayake E.M.H.E.B., Rathnayake A.R.M.A.N., Abeysekara A.M.R., Oorloff T.S.J., Herath H.M.V.R., Godaliyadda G.M.R.I., Ekanayake M.P.B. \& Senaratne A.) 47: 271-284 (2019)

\section{Retrofitting}

Performance of un-reinforced burned clay brick masonry walls retrofitted with locally available materials (Mendis W.S.W., De Silva G.S.Y. \& De Silva G.H.M.J.S.) 47: 29-38 (2019)

Reversible logic

Design of fault-tolerant reversible Vedic multiplier in quantum cellular automata (Kamaraj A. \& Marichamy P.) 47: 371-382 (2019)

\section{Rough bark disease severity}

Intensity of leaf spot and rough bark diseases in cinnamon accessions collected from major cinnamon growing areas of Sri Lanka (Azad R., Kumara K.L.W., Senanayake G., Ranawaka R.A.A.K., Pushpakumara D.K.N.G. \& Geekiyanage S.) 47: 297-305 (2019)

\section{Runtime validation}

Integrating runtime validation and hardware-in-the-loop (HiL) testing with V \& V in complex hybrid systems (Dewasurendra S.D., Vidarapathirana A.C. \& Abeyratne S.G.) 47: 393-408 (2019)

\section{Sanger sequencing}

Evaluating novel effective primers to amplify heterozygous alleles of second, third and fourth exons of HLA-A; -B; -C; -DRB1 and -DQB1 loci using sequencing-based typing (Perera P.C.D., Upamali B.D.N., Gunawardene Y.I.N.S. \& Dassanayake R.S.) 47: 341-348 (2019)

\section{Seasonal rainfall}

Trends in extreme rainfall events in Sri Lanka,1961-2010 (Thevakaran A., Suppiah R. \& Sonnadara U.) 47: 285-295 (2019)

\section{Secondary user}

Human opinion dynamics-based optimization for in-band spectrum sensing in cognitive radio networks (Garg R. \& Saluja N.) 47: 467-477 (2019)

\section{Sediment transport}

Numerical modelling of the spatial variation of sediment transport using wave climate schematization method - a case study of west coast of Sri Lanka (Jayathilaka R.M.R.M. \& Fernando M.C.S.) 47: 421-433 (2019)

\section{Sediment}

Sedimentary geochemistry of alluvial overburden in the primary gem deposit of Pelmadulla, Sri Lanka (Jayawardana D.T., Madusanka R.M.T.D., Jayasinghe R.M.N.P.K., Adikaram A.M.N.M. \& Udagedara D.T.) 47: 221-234 (2019)

\section{Sedimentary geochemistry}

Sedimentary geochemistry of alluvial overburden in the primary gem deposit of Pelmadulla, Sri Lanka (Jayawardana D.T., Madusanka R.M.T.D., Jayasinghe R.M.N.P.K., Adikaram A.M.N.M. \& Udagedara D.T.) 47: 221-234 (2019)

\section{Sediment-water interface}

Molecular indicators of early stage diagenesis in the tropical coastal Bolgoda Lake, Sri Lanka (Ratnayake A.S., Sampei Y. \& Ratnayake N.P.) 47: 69-77 (2019)

\section{Seedling growth}

Germination and seedling growth responses of Sri Lankan grown sesame/thala (Sesamum indicum L.) for simulated drought Conditions (Dissanayake I.A.J.K., Ranwala S.M.W. \& Perera S.S.N.) 47: 479-490 (2019)

\section{Seismic resistant}

Performance of un-reinforced burned clay brick masonry walls retrofitted with locally available materials (Mendis W.S.W., De Silva G.S.Y. \& De Silva G.H.M.J.S.) 47: 29 - 38 (2019)

\section{Seismic surveys}

Estimating sedimentary thickness of Lanka Basin using digitized scanned seismic sections (Silva K.C.C., Gamage N.G.S.S. \& Weerasinghe D.A.) 47: 357-362 (2019)

\section{Sesame}

Germination and seedling growth responses of Sri Lankan grown sesame/thala (Sesamum indicum L.) for simulated drought Conditions (Dissanayake I.A.J.K., Ranwala S.M.W. \& Perera S.S.N.) 47: 479-490 (2019)

SGC

Aggregate interlocking of open-graded friction courses with compaction effort (Mampearachchi W.K., Masakorala S.R. \& Umasangar K.) 47: 139146 (2019)

\section{Silver}

Silver-montmorillonite-conducting polymer composite materials as low-cost oxygen reduction catalysts (Senarathna K.G.C. \& Rajapakse R.M.G.) 47: 409-420 (2019) 


\section{Social force}

Comparative study of deterministic and stochastic pedestrian motions (Pradhan R.K., Shrestha S. \& Tiwari S.) 47: 213-220 (2019)

\section{Sri Lanka}

Austroeupatorium inulifolium invasion alters litter dynamics in Cymbopogon nardus-dominated manmade grasslands (Piyasinghe I.P.K., Gunatilake J. \& Madawala H.M.S.P.) 47: 39-49 (2019)

\section{Sri Lanka}

Chemical composition and gross energy content of commonly available animal feedstuff in Sri Lanka (Pavithra S., Vidanarachchi J.K., Sarmini M. \& Premaratne S.) 47: 79-87 (2019)

\section{Stability analysis}

Mathematical model for malaria with mosquito-dependent coefficient for human population with exposed class (Singh R., Ali S., Jain M. \& Raina A.A.) 47: $185-198$ (2019)

\section{Stock identification}

Some biological aspects and molecular variations in frigate tuna, Auxis thazard of the coastal waters around Sri Lanka (Herath D.R., Perera H.A.C.C. \& Hettiarachchi G.H.C.M.) 47: 333-340 (2019)

\section{Stratified random sampling}

Utilising bivariate auxiliary information for enhanced estimation of population mean under simple and stratified random sampling schemes (Javed M., Irfan M. \& Pang T.) 47: 199-211 (2019)

\section{Structure}

Structural form as an analogical source for structures of nature: two examples (Dias P. \& Hahn R.) 47: 323-331 (2019)

\section{Sulphuric acid attack}

Durability properties of alkali pozzolan cement (APC) (Kulasuriya C., Dias W.P.S. \& Vimonsatit V.) 47: 121-131 (2019)

\section{SWAN}

Numerical modelling of the spatial variation of sediment transport using wave climate schematization method - a case study of west coast of Sri Lanka (Jayathilaka R.M.R.M. \& Fernando M.C.S.) 47: 421-433 (2019)

\section{Symmetric division index}

Computational aspects of line graph of carbon nanocones (Hussain Z., Munir M., Nazeer W., Saleem M.S., Kang S.M. \& Kwun Y.C.) 47: 435-443 (2019)

Taste and odour

Geosmin contamination status of raw and treated waters in Sri Lanka (Ganegoda S., Chinthaka S.D.M. \& Manage P.M.) 47: 245-259 (2019)

\section{Temperature}

Varietal diversity of Sri Lankan traditional rice based on sensitivity to temperature and photoperiod at vegetative stage (Rathnathunga E.U.U., Senanayake G., Seneweera S. \& Geekiyanage S.) 47: 51-68 (2019)

\section{Tetracycline (TET)}

Occurrence and distribution of tetracycline resistance determinants and their pollution profile in selected aquaculture environments in Sri Lanka (Liyanage G.Y. \& Manage P.M.) 47: 455-465 (2019)

\section{Text classification}

Efficient label ordering for improving multi-label classifier chain accuracy (Ali T. \& Asghar S.) 47: 175-184 (2019)

\section{Thermostable}

Isolation of a cellulase producing Bacillus cereus from cow dung and determination of the kinetic properties of the crude enzyme (Croos A.M.B., Rajendran S. \& Ranganathan K.) 47: 261-267 (2019)

\section{Thickness model}

Estimating sedimentary thickness of Lanka Basin using digitized scanned seismic sections (Silva K.C.C., Gamage N.G.S.S. \& Weerasinghe D.A.) 47: 357-362 (2019)

Time fractional Boussinesq type equation

Closed form wave solutions to the time fractional Boussinesq-type equation and the Zakharov-Kuznetsov equation (Islam M.N., Khan Md. A. \& Akbar M.A.) 47: 149-160 (2019)

\section{Time fractional ZK equation}

Closed form wave solutions to the time fractional Boussinesq-type equation and the Zakharov-Kuznetsov equation (Islam M.N., Khan Md. A. \& Akbar M.A.) 47: 149-160 (2019)

\section{Titanate coupling agent}

Effect of an organotitanate coupling agent on properties of calcium carbonate filled low-density polyethylene and natural rubber composites (Sampath W.D.M., Egodage S.M. \& Edirisinghe D.G.) 47: 17-27 (2019) 


\section{Tomato}

Effect of micronutrient fortified fertiliser application on the growth and yield components of tomato plant in floodplain soils of Bangladesh (Sarker Md. M.H., Moslehuddin A.Z. Md., Jahiruddin M., Islam M.R. \& Talukder R.) 47: 161-168 (2019)

\section{Topological indices}

Hosoya polynomial and topological indices of $n$-linear benzene (Nizami A.R., Idrees M., Amin N. \& Iqbal Z.) 47: 169-174 (2019)

\section{Traditional rice}

Varietal diversity of Sri Lankan traditional rice based on sensitivity to temperature and photoperiod at vegetative stage (Rathnathunga E.U.U., Senanayake G., Seneweera S. \& Geekiyanage S.) 47: 51-68 (2019)

\section{Transgenic rice}

Cloning and characterization of an endosperm specific glutelin Blpromoter from Sri Lankan rice (Oryza sativa L. ssp. indica) variety Bg 250 (Kajendran K., Chandrasekharan N.V., Hettiarachchi C.M., Nanayakkara A.K., Elvitigala A.S. \& Wijesundera W.S.S.) 47: 383-391 (2019)

Transmission dynamics

Mathematical model for malaria with mosquito-dependent coefficient for human population with exposed class (Singh R., Ali S., Jain M. \& Raina A.A.) 47: 185-198 (2019)

\section{Travelling wave transformation}

Closed form wave solutions to the time fractional Boussinesq-type equation and the Zakharov-Kuznetsov equation (Islam M.N., Khan Md. A. \& Akbar M.A.) 47: 149-160 (2019)

TSS

Distributed modelling of water resources and pollute transport in Malwathu Oya Basin, Sri Lanka (Dahanayake A.C. \& Rajapakse R.L.H.L.) 47: 307-321 (2019)

\section{Two normal linear models}

Estimation of the parameters in two linear models with some of the identical parameter vectors under the Pitman's closeness criterion (Wu J.) 47: 363-368 (2019)

\section{Un-reinforced brick masonry}

Performance of un-reinforced burned clay brick masonry walls retrofitted with locally available materials (Mendis W.S.W., De Silva G.S.Y. \& De Silva G.H.M.J.S.) 47: 29-38 (2019)

Urdhwa Triyakbhyam

Design of fault-tolerant reversible Vedic multiplier in quantum cellular automata (Kamaraj A. \& Marichamy P.) 47: 371-382 (2019)

\section{V\&V - testing integration}

Integrating runtime validation and hardware-in-the-loop (HiL) testing with V \& V in complex hybrid systems (Dewasurendra S.D., Vidarapathirana A.C. \& Abeyratne S.G.) 47: 393-408 (2019)

\section{Vedic multiplication}

Design of fault-tolerant reversible Vedic multiplier in quantum cellular automata (Kamaraj A. \& Marichamy P.) 47: 371-382 (2019)

\section{Water absorption}

Durability properties of alkali pozzolan cement (APC) (Kulasuriya C., Dias W.P.S. \& Vimonsatit V.) 47: 121-131 (2019)

\section{WEP model}

Distributed modelling of water resources and pollute transport in Malwathu Oya Basin, Sri Lanka (Dahanayake A.C. \& Rajapakse R.L.H.L.) 47: 307-321 (2019)

\section{Wet days}

Trends in extreme rainfall events in Sri Lanka,1961-2010 (Thevakaran A., Suppiah R. \& Sonnadara U.) 47: 285-295 (2019)

\section{Zagreb index}

Computational aspects of line graph of carbon nanocones (Hussain Z., Munir M., Nazeer W., Saleem M.S., Kang S.M. \& Kwun Y.C.) 47: 435-443 (2019) 